\title{
A DISSEMINAÇÃO DA CAFEICULTURA NO SUL DE MINAS GERAIS E NO MUNICÍPIO DE NEPOMUCENO-MG
}

\author{
The dissemination of the coffee production in the South of \\ Minas Gerais and in the municipality of Nepomuceno-MG
La diseminación de la caficultura en el Sur de Minas Gerais y en el municipio de Nepomuceno-MG

\section{Lucas Guedes Vilas Boas*}

\author{
*Doutor em Geografia (UFMG) - lucasgvb1991@hotmail.com
}

\author{
Recebido em 11/05/2020. Aceito para publicação em 19/06/2020 \\ Versão online publicada em 04/07/2020 (http://seer.ufrgs.br/paraonde)
}

\section{Resumo:}

A porção sul do estado de Minas Gerais é a maior produtora de café do Brasil. Diversos elementos contribuíram para a disseminação das lavouras cafeeiras na região. Assim, o objetivo do artigo foi discutir como ocorreu a difusão da cafeicultura na região de planejamento Sul de Minas e no município de Nepomuceno. Destarte, abordou-se alguns temas que colaboraram para o crescimento da cafeicultura regional e municipal ou impactaram o setor cafeeiro nacional, como o trabalho escravo, a construção das ferrovias e a chegada de imigrantes italianos. Os procedimentos metodológicos adotados foram a pesquisa bibliográfica e a análise documental. A mão de obra escrava foi importante para a disseminação da cafeicultura nos municípios sul-mineiros. Ademais, as ferrovias também tiveram papel crucial, pois possibilitaram o escoamento da produção cafeeira da região, bem como a chegada de imigrantes italianos para trabalharem nos cafezais. No início do século XX, o milho, a canade-açúcar e o café eram os principais produtos agrícolas de Nepomuceno. Os imigrantes italianos vindos do estado de São Paulo, que imigraram para o município em virtude da crise do café do início dos anos 1900, contribuíram para a disseminação da cafeicultura em escala municipal na primeira metade do século XX. No entanto, alguns problemas no transporte, como o alto custo e a lentidão, dificultaram o êxito do setor cafeeiro em Nepomuceno até o decênio de 1930.

Palavras-chave: Cafeicultura. Sul de Minas. Nepomuceno-MG. Trabalho. Geografia Histórica.

\begin{abstract}
:
The southern portion of Minas Gerais' state is the largest coffee producer in Brazil. Several elements contributed to the dissemination of the coffee plantations in the region. Thus, the objective of the article was to discuss how occured the dissemination of the coffee growing in South of Minas planning region and in municipality of Nepomuceno. Thus, was discussed some themes that contributed to the growth of the regional and municipal coffee production or impacted the national coffee sector, such as slave labor, the construction of railways and the arrival of Italian immigrants. The methological procedures adopted were bibliographic research and documental analysis. Slave labor was important for the dissemination of coffee production in the municipalities of South of Minas Gerais. Furthermore, the railways also played a crucial role, as they enabled the coffee
\end{abstract}


production distribution of the region, as well as the arrival of Italian immigrants to work in the coffee plantations. At the beginning of the 20th century, corn, sugar cane and coffee were the main agricultural products of Nepomuceno. Italian immigrants from the state of São Paulo, who migrated to the municipality due to the coffee crisis of the early 1900s, contributed to the dissemination of coffee on a municipal scale in the first half of the 20th century. However, some transport problems, such as high cost and slowness, hampered the success of the coffee sector in Nepomuceno until the 1930s.

Keywords: Coffee Production. South of Minas. Nepomuceno-MG. Labor. Historical Geography.

\begin{abstract}
Resumen:
La porción sur del estado de Minas Gerais es la mayor productora de café del Brasil. Varios elementos contribuyeron para la diseminación de los cultivos cafeteros en la región. Así, el objetivo del articulo fue discutir como ocurió la difusión de la caficultura en la región de planeamiento Sul de Minas y en el municipio de Nepomuceno. De esta manera, se abordó algunos temas que colaboraron para el crecimiento de la caficultura regional y municipal o impactaran el sector cafetero nacional, como el trabajo escravo, la construcción de las ferrovias y la llegada de imigrantes italianos. Los procedimientos metodológicos adoptados fueron la investigación bibliográfica y el análisis documental. La mano de obra esclava fué importante para la diseminación de la caficultura en los municipios del Sur de Minas. Además, las vías férreas también tuvieron papel crucial, pues posibilitaran el transporte de la producción cafetera de la región, así como la llegada de imigrantes italianos para trabajaren en los cafezales. En princípio del siglo XX, maiz, cana-de-açúcar y café eran los principales produtos agrícolas de Nepomuceno. Los imigrantes italianos vindos del estado de São Paulo, que migraran para el municipio debido a la crisis del café del início de los años 1900, contribuyeron para la diseminación de la caficultura en escala municipal en la primera mitad del siglo XX. Sin embargo, algunos problemas en el transporte, como el alto costo y la lentitud, dificultaron el éxito del sector cafetero en Nepomuceno hasta el decénio de 1930.
\end{abstract}

Palabras clave: Caficultura. Sur de Minas. Nepomuceno-MG. Trabajo. Geografía Histórica.

\title{
1. Introdução
}

A configuração da estrutura agrária dos municípios sul-mineiros, inclusive de Nepomuceno, foi historicamente influenciada pela cafeicultura. Assim, 0 artigo realiza uma breve discussão acerca dos aspectos históricos que contribuíram para a disseminação das lavouras cafeeiras no município e na região de planejamento Sul de Minas Gerais. Ademais, dialoga com o contexto histórico nacional e mundial, a fim de melhorar a compreensão acerca da cafeicultura e de propagação em terras sul-mineiras e nepomucenenses, visto que o café é um gênero fundamental para o seu Produto Interno Bruto (PIB).

Sob esse prisma, Vaca (2013) e Vilas Boas (2016; 2019) enaltecem a relevância dos avanços nos meios de transporte e de comunicação para o desenvolvimento da economia local e regional, sobretudo da agropecuária, pois facilitaram o escoamento da produção cafeeira. A mão de obra escrava, assim

ParaOnde!?, Porto Alegre, v.13, n.1, p.189-213, 2020.http://seer.ufrgs.br/paraonde 
como a imigrante (com destaque para os italianos), também é abordada, uma vez que colaborou para o crescimento da cafeicultura na região.

A porção sul do estado de Minas Gerais se destaca na cafeicultura desde o século XIX. De acordo com a Fundação João Pinheiro (1992), a região de planejamento Sul de Minas (Figura 01) possui 155 municípios, os quais, de acordo com os dados do IBGE, produziram 888.616 toneladas de café em 2018. Assim, os municípios sul-mineiros foram responsáveis por $46,75 \%$ da produção estadual e $24,98 \%$ da produção nacional da rubiácea. Dentre os 907.209 hectares destinados às lavouras temporárias e permanentes no Sul de Minas em 2018, 459.712 hectares $(50,67 \%)$ foram direcionados à cafeicultura (IBGE, 2019a).

Figura 01 - Regiões de Planejamento de Minas Gerais

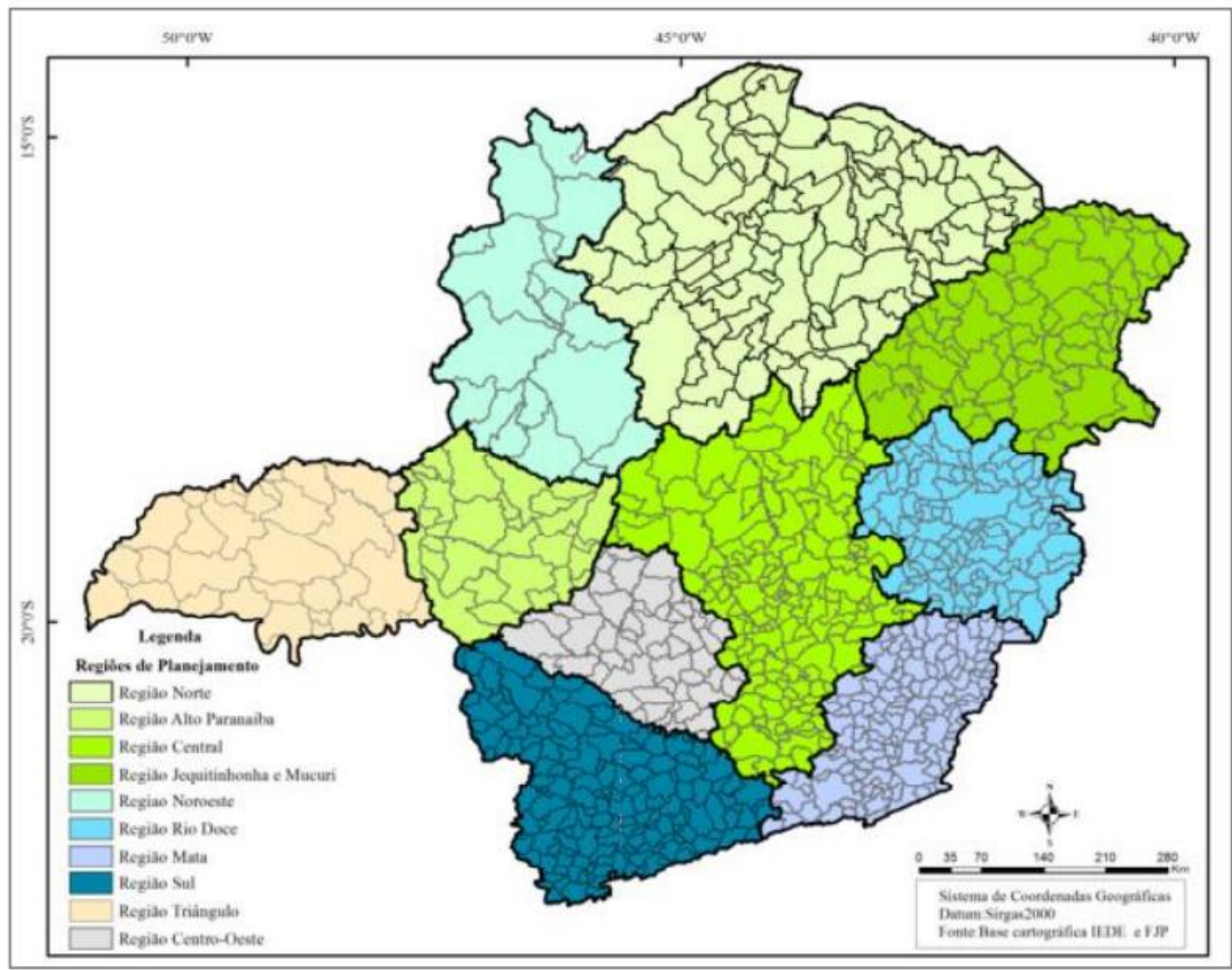

Fonte: Pereira, Hespanhol (2015)

Em 2017, a região de planejamento Sul de Minas teve o Produto Interno Bruto (PIB) de $\mathrm{R} \$ 77.933 .177 .000,00$, sendo responsável por $13,51 \%$ do PIB estadual (IBGE, 2019b). A região faz divisa com o estado de São Paulo e possuía uma população estimada de 2.821.728 habitantes no ano de 2019 (IBGE, 2019c).

O artigo está dividido em cinco partes, excetuando-se a introdução, a metodologia e as considerações finais. De antemão, apresenta-se um breve

ParaOnde!?, Porto Alegre, v.13, n.1, p.189-213, 2020.http://seer.ufrgs.br/paraonde 
histórico acerca da disseminação dos cafeeiros no mundo e no Brasil, salientando os principais elementos que colaboraram para a propagação das lavouras cafeeiras. Na sequência, é abordada a importância do trabalho escravo para o êxito da cafeicultura no Sul de Minas Gerais no século XIX. A contribuição do ferroviarismo para a cafeicultura regional na transição entre os séculos XIX e XX também foi discutida. Por fim, são apresentadas as principais características da produção agropecuária do município de Nepomuceno entre as décadas de 1910 e 1920, mostrando como ocorreu o crescimento da cafeicultura municipal na primeira metade dos novecentos.

\section{Metodologia}

Desta maneira, o artigo articulou, por meio de pesquisa documental desenvolvida com análise de fontes primárias (especialmente os dados divulgados pelo Arquivo Público Mineiro e pelo Instituto Brasileiro de Geografia e Estatística) e pesquisa bibliográfica realizada por intermédio de fontes secundárias (principalmente artigos e livros científicos), um breve histórico acerca da disseminação da cafeicultura na porção sul do território de Minas Gerais e no município de Nepomuceno.

A pesquisa de caráter documental se destina à análise detalhada e criteriosa de fontes primárias (dados e estatísticas, elementos iconográficos, textos literários, técnicos, entre outros) que não passaram por tratamento científico e apresentam dados originais. Assim, os documentos empregados devem ser selecionadas de acordo com o objetivo e o tema da pesquisa. Além disso, a análise de conteúdo deve ser realizada de maneira apurada, para assegurar que as informações presentes nos documentos sejam interpretadas de forma apropriada (OLIVEIRA, 2012; SILVA; MENDES, 2013).

Portanto, a análise documental é uma excelente fonte de dados e informações para os estudos científicos. Mesmo que os documentos analisados sejam antigos, conseguem representar conjunturas de outros períodos e providenciar informações sobre diversos assuntos, uma vez que foram elaborados e produzidos em determinada escala espaço-temporal (OLIVEIRA, 2012; SILVA; MENDES, 2013).

Os dados concernentes à produção agrícola da região de planejamento Sul de Minas foram coletados no documento intitulado Produção Agrícola Municipal 2018, publicado pelo IBGE (IBGE, 2019a). Somou-se a produção cafeeira de todos os 155 municípios da região no ano de 2018, bem como os hectares destinados às lavouras temporárias e permanentes, assim como à cafeicultura, no mesmo ano. Ademais, os dados do PIB de todos os municípios da região, divulgados pelo IBGE (IBGE, 2019b), foram agrupados e comparados ao PIB estadual.

Os dados relativos ao número de escravos em Minas Gerais, no Sul de Minas e em Nepomuceno foram obtidos por meio da análise das Listas Nominativas de Habitantes de 1831-1832, publicadas pelo Arquivo Público Mineiro (ARQUIVO PÚBLICO MINEIRO, 1832). Já os números referentes à produção agrícola e ao valor estimado da produção no município de

ParaOnde!?, Porto Alegre, v.13, n.1, p.189-213, 2020.http://seer.ufrgs.br/paraonde 
Nepomuceno em 1918 foram divulgados no documento intitulado Estatística do Município de Nepomuceno. Tais dados resultaram de um recenseamento realizado pela Prefeitura Municipal no ano de 1918 (PREFEITURA MUNICIPAL DE NEPOMUCENO, 1918). A edição do periódico Nação Brasileira destinada ao município de Nepomuceno forneceu importantes informações sobre a composição da população nepomucenense no começo dos novecentos, a economia e a agropecuária municipais no final do século XIX e início do século XX (NAÇÃO BRASILEIRA, 1925).

\section{Os primórdios da cafeicultura em território brasileiro}

O café é originário da região de Kaffa, situada no interior da Etiópia, antiga Abissínia, onde o cafeeiro era uma planta típica do bioma local. Os etíopes consumiam o grão amassado e/ou mergulhado em gordura animal e bebiam um chá preparado com suas folhas. Também produziam uma bebida alcoólica preparada através da fermentação do grão. Segundo a tese mais aceita, a rubiácea foi levada, entre os séculos VI e IX, da África para o Oriente Médio por africanos que migraram em direção à Península Arábica, principalmente ao lêmen. Neste contexto, os árabes foram os pioneiros no cultivo do café (TAUNAY, 1939; MARTINS, 1990; SOUZA, 2006).

Martins (1990), Topik (2003) e Frederico (2013) esclarecem que o início da comercialização da rubiácea em larga escala aconteceu no século $X V$, com o cultivo em solo iemenita e a venda efetuada pelos árabes. Até o século XVII, o café era uma especiaria restrita aos países muçulmanos. A partir do final dos seiscentos, o grão adentrou a economia europeia, contudo, ainda prosseguiu como um produto de luxo destinado ao consumo das elites. De origem muçulmana, superou a resistência europeia em relação a uma bebida não cristã. $\mathrm{Na}$ segunda metade do período oitocentista, o café se tornou um gênero consumido pelas massas. Diversas potências imperialistas, como Inglaterra e Holanda, iniciaram a cafeicultura em muitas de suas colônias, como Guiana, Cuba, Suriname e Indonésia. Ademais, um dos elementos que contribuiu para sua popularização foi o crescimento da produção cafeeira no Brasil, financiado pela aplicação de capitais oriundos do ascendente setor industrial inglês.

Por meio de empréstimos, estes investimentos fomentaram a consolidação da infraestrutura necessária à produção e à circulação do café, sobretudo através da construção de ferrovias e portos. Os avanços no transporte marítimo e a difusão das vias férreas em território nacional promoveram a ampliação do comércio do café brasileiro em escala mundial (FREDERICO, 2013). A elevada oferta de terras e de mão de obra disponível ao trabalho na cafeicultura propiciou o crescimento da produção no Brasil e a contração dos preços desta commodity em âmbito internacional (TOPIK, 2003; FREDERICO, 2013).

De acordo com Reclus (1900) e Taunay (1939), os primeiros cafeeiros cultivados no Brasil foram plantados em 1727 no município de Belém, localizado na província do Grão-Pará, disseminando-se da capital paraense para o restante do território nacional. De Belém, o café foi levado para São Luís, no Maranhão e, posteriormente, na década de 1760, para terras fluminenses, de onde a cultura

ParaOnde!?, Porto Alegre, v.13, n.1, p.189-213, 2020.http://seer.ufrgs.br/paraonde 
se difundiu para os demais estados da região Sudeste. Segundo fontes oficiais, o sargento-mor Francisco de Mello Palheta levou clandestinamente as primeiras mudas cafeeiras para o Brasil, as quais foram um presente da madame Claude D'Orvilliers, esposa do então governador de Caiena, atual capital da Guiana Francesa (MARTINS, 1990; ARAÚJO FILHO, 1992; SOUZA, 2006; WATSON; ACHINELLI, 2008).

Giovanini (2006) afirma que o Caminho Velho promoveu o surgimento de diversas cidades no sul de Minas durante o século XVIII, como Lavras, Ingaí, Três Pontas, Varginha e Três Corações, todas próximas à atual localização de Nepomuceno. Coelho (2015) salienta que a partir de 1720 ocorreu expressivo movimento migratório para a região de Lavras, antiga Lavras do Funil, em razão de seu potencial aurífero, com destaque para Ribeirão Vermelho. Desde os setecentos, a pecuária e a produção de alimentos eram desenvolvidas nos municípios sul-mineiros, visando o autoconsumo e o abastecimento dos mercados intra e interprovinciais, como a região mineradora e o mercado fluminense, respectivamente. À época, a economia regional era conhecida pela produção de gêneros agropecuários de subsistência. Tais atividades demandavam significativo contingente de trabalhadores, justificando a grande concentração de escravos no sul de Minas Gerais nos séculos XVIII e XIX (PASCOAL, 2005; 2007; CASTILHO, 2009). Nesta esfera, Martins (1980) advoga que a volumosa população escrava em Minas Gerais nos séculos XVIII e XIX resultou da grande importação de cativos neste período.

Nos setecentos, além dos gêneros alimentícios, tabaco, algodão e aguardente de cana também possuíam alguma expressividade nas exportações sul-mineiras. A região era caracterizada pela policultura, com o cultivo de diversos gêneros agrícolas, diferindo-se do panorama atual, marcado pela monocultura cafeeira (PASCOAL, 2005; 2007; CASTILHO, 2009; SILVA, 2012). No tocante ao assunto, Topik (2003) e Souza (2006) argumentam que o êxito da Revolução Haitiana no final do século XVIII favoreceu a difusão da cultura cafeeira para outros países, beneficiando os demais produtores, pois promoveu a elevação dos preços do grão no mercado internacional.

A Revolução Haitiana ocorreu entre 1791 e 1804, reverberando na independência do país e no fim da escravidão em seu território. Ao fim do conflito, cidadãos afrodescendentes assumiram o poder em solo haitiano. Durante a contenda, grupos revoltosos de escravos destruíram inúmeras lavouras cafeeiras, sobretudo pertencentes aos latifundiários de origem francesa. Assim sendo, como o Haiti era um dos maiores produtores de café da época, a eliminação de muitos de seus cafezais reduziu a oferta do gênero no mercado, repercutindo no aumento de seu preço venal (TOPIK, 2003).

Destarte, no decênio de 1830, o Brasil alcançou o posto de maior produtor da rubiácea em escala mundial, com sua produção cafeeira concentrada na região do Vale do Paraíba. Neste mesmo período, houve ampliação da demanda mundial de café, sobretudo em decorrência da industrialização das maiores economias europeias. No último quartel do século XIX, o café se tornou o principal produto da economia brasileira (TAUNAY, 1939; HOLLOWAY, 1978; WATSON; ACHINELLI, 2008).

ParaOnde!?, Porto Alegre, v.13, n.1, p.189-213, 2020.http://seer.ufrgs.br/paraonde 
As primeiras lavouras cafeeiras do sul de Minas Gerais foram instaladas em Aiuruoca, Baependi e Jacuí, no final do século XVIII, pelos tropeiros que realizavam o trajeto entre o Rio de Janeiro e o sul de Minas e pelos boiadeiros cuja função era transportar o gado do sul do estado em direção ao Rio de Janeiro (FILETTO, 2000). Salienta-se que os primeiros cafeeiros cultivados em terras mineiras apresentavam produção incipiente e eram destinados ao autoconsumo, pois conforme esclarece Barbosa (2016), a rubiácea figurou nas estatísticas de exportações do estado somente a partir do início dos oitocentos. A maioria dos víveres oriundos da agropecuária era direcionada ao mercado interno, enquanto outra parte era exportada, tanto para a região mineradora, quanto para 0 município do Rio de Janeiro, então sede da Corte portuguesa no Brasil. No princípio do período oitocentista, o desenvolvimento da agropecuária e a ocupação de áreas rurais próximas a Lavras do Funil dinamizaram economicamente o sul de Minas Gerais (PASCOAL, 2005; COELHO, 2015).

Segundo Holloway (1978), no século XIX, após o declínio do período minerador, Minas Gerais, assim como a região Sudeste, reunia condições propícias à cafeicultura, pois possuía grande oferta de terras, disponibilidade de mão de obra escrava e elevado número de consumidores. A crise da mineração e o menor desgaste dos escravos na agropecuária, cuja consequência era o prolongamento do tempo de vida dos cativos, contribuíram para o desenvolvimento da agricultura em Minas Gerais, inclusive no sul do estado (COELHO, 2015). Como o café não se adaptou bem às terras do alto das Serras do Mar e da Mantiqueira em virtude das baixas temperaturas, o cultivo da rubiácea foi levado para os municípios sul-mineiros cuja altitude é inferior a 1300 metros, condição ideal à cafeicultura (COELHO, 2012).

A vinda da família real portuguesa ao Brasil no princípio do século XIX dinamizou a economia sul-mineira, pois a região se tornou a principal fonte dos gêneros alimentícios consumidos pelos membros da Corte, destacando-se no abastecimento intra e interprovincial de laticínios, cereais, carne bovina, suína e aviária através das rotas terrestres. Tal fato reverberou no crescimento da concessão de sesmarias nos municípios do sul de Minas, tanto para povoamento, quanto para agricultura, uma vez que a região carecia de mão de obra para a produção de alimentos. No início do século XIX, a construção da Estrada do Comércio e da Estrada da Polícia auxiliou na ligação dos municípios sul-mineiros ao estado do Rio de Janeiro (GIOVANINI, 2006; CASTILHO, 2012; MARTINS, 2013).

Nos primeiros decênios do período oitocentista, a cafeicultura brasileira estava concentrada no Vale do Paraíba paulista e fluminense e na Zona da Mata mineira. A produção cafeeira nacional, controlada pela aristocracia rural, estava assentada na tríade monocultura, escravismo e latifundiarismo, típica do sistema de plantation. Parcela da mão de obra escrava utilizada durante o auge da mineração também foi explorada nas primeiras áreas cafeicultoras (ARAÚJO FILHO, 1992). Pascoal $(2005 ; 2007)$ afirma que poucos foram os escravos da mineração aproveitados para o trabalho nos cafezais, diminuindo a importância conferida aos mesmos por Araújo Filho (1992). Com um ponto de vista semelhante ao de Pascoal (2007), Martins (1980) argumenta que a população escrava apresentou grande crescimento na primeira metade dos oitocentos,

ParaOnde!?, Porto Alegre, v.13, n.1, p.189-213, 2020.http://seer.ufrgs.br/paraonde 
época em que a cafeicultura ainda era incipiente em território mineiro. Destarte, o autor defende que o elevado contingente de escravos em Minas Gerais no período oitocentista não guarda relações com a difusão dos cafezais pelo estado.

Durante o século XIX, o consumo de café se tornou um costume dos cidadãos estadunidenses, promovendo grande acréscimo na demanda internacional da rubiácea. Neste âmbito, sublinha-se que os Estados Unidos isentavam o café brasileiro de tarifas alfandegárias, beneficiando os produtores do país e estimulando o plantio de novos cafezais (ARAÚJO FILHO, 1992).

No princípio dos oitocentos, a policultura e a produção de autossuficiência eram pujantes em Minas Gerais e a maior parte dos escravos era empregada nestas atividades. A maioria das propriedades agrícolas mineiras produzia para autoconsumo e para o comércio em mercados locais (MARTINS, 1980). Nesta conjuntura, o Sul de Minas era a região mais dinâmica do estado na primeira metade do século XIX, sobretudo em função da agricultura de subsistência volvida ao comércio. Neste período, as propriedades agrícolas sul-mineiras eram caracterizadas pela policultura e o cuidado com o gado geralmente era tarefa exercida pelos escravos, embora já houvesse, em menor quantidade, uso de mão de obra familiar em outras atividades (GIOVANINI, 2006). No século XIX, as lavouras sul-mineiras eram plantadas nas partes mais baixas do relevo, nas proximidades dos cursos d'água. As áreas mais elevadas das propriedades rurais, como os topos de morro, eram destinadas às reservas florestais, nas quais os proprietários obtinham lenha e madeira para autoconsumo, caçavam e coletavam espécies vegetais utilizadas para fins medicinais e nas dietas alimentares (MARTINS, 2014b).

Na primeira metade dos oitocentos, o fumo e o toucinho eram os principais gêneros comerciais sul-mineiros, respectivamente. Aproximadamente $80 \%$ da produção de fumo regional era voltada à exportação. Somente no final do século XIX, outros gêneros, como café e alguns cereais, aproximaram-se dos índices de exportação de fumo. Sublinha-se que a importância do toucinho corrobora a importância do gado suíno para a economia do sul de Minas no período em questão. No panorama nepomucenense, os principais gêneros agrícolas cultivados no início do século XIX eram cereais, como milho e feijão, mas também se destacavam a produção de fumo, algodão, cana-de-açúcar e seus derivados, além da pecuária suína. À época, a extração de madeira era uma atividade expressiva na conjuntura municipal. Também havia a venda de queijos, em pequena escala, para municípios adjacentes (SILVA, 2012).

\section{O trabalho escravo e a cafeicultura no Sul de Minas e em Nepomuceno no século XIX}

Em Nepomuceno, a força de trabalho escrava, muito empregada na agropecuária, teve suma importância para o desenvolvimento da economia local. No século XIX, o então distrito de São João Nepomuceno, atual Nepomuceno, destacava-se pela expressiva quantidade de escravos no município. De acordo com informações das listas nominativas do Recenseamento de 1831/1832 disponibilizadas pelo Arquivo Público Mineiro, no ano de 1831, o distrito de São João Nepomuceno, vinculado à comarca de São João Del Rei, possuía 172

ParaOnde!?, Porto Alegre, v.13, n.1, p.189-213, 2020.http://seer.ufrgs.br/paraonde 
fogos, com um total de 2595 moradores, dos quais 1240 eram escravos. Portanto, à época, quase metade dos nepomucenenses eram escravos. Dentre os 172 fogos do município, 120 possuíam escravos, percentual bastante expressivo. Em Nepomuceno, predominavam os fogos com reduzido número de escravos, pois de modo geral, as propriedades agrícolas possuíam diminutas dimensões. Mais da metade dos 1240 escravos de Nepomuceno, totalizando um quantitativo de 644, eram de origem africana, enquanto 596 eram crioulos, nascidos em território brasileiro (ARQUIVO PÚBLICO MINEIRO, 1832).

No início dos oitocentos, Nepomuceno possuía um percentual de escravos significativamente elevado em comparação aos demais municípios do sul de Minas Gerais e ao estado como um todo. Neste sentido, Giovanini (2006) mostra que entre os anos de 1831 e 1832, Minas Gerais possuía uma população total de 400.549 habitantes, dos quais 128.116 eram escravos. Já a região sul do estado contabilizava 105.912 moradores, com um contingente de 34.328 escravos. O geógrafo, assim como Martins (1980), salientam que o maior percentual de escravos da região, assim como do estado, concentrava-se na faixa etária entre os 15 e 44 anos, a fase adulta, na qual os indivíduos estavam mais aptos fisicamente ao trabalho braçal. Coelho (2015) afirma que a maioria da população escrava, tanto no sul de Minas, quanto no restante da unidade federativa, era composta por homens. Ao comparar a situação escravista de Nepomuceno com a de outros distritos mineiros, como Perdões e Luminárias, o autor observa que na primeira metade do período oitocentista, Nepomuceno possuía um percentual maior de propriedades com escravos (COELHO, 2015). Sob esse prisma, a tabela 01 evidencia as palavras do autor:

Tabela 01 - Minas Gerais, Sul de Minas e Nepomuceno: População Total, Quantidade e Percentual Total de Escravos em 1831-1832

\begin{tabular}{cccc}
\hline & Minas Gerais & Sul de Minas & Nepomuceno \\
\hline $\begin{array}{c}\text { População } \\
\text { Total }\end{array}$ & 400.549 & 105.912 & 2.595 \\
$\begin{array}{c}\text { Número de } \\
\text { Escravos }\end{array}$ & 128.116 & 34.328 & 1240 \\
$\begin{array}{c}\text { Percentual de } \\
\text { Escravos }\end{array}$ & $31,99 \%$ & $32,41 \%$ & $47,78 \%$ \\
\hline
\end{tabular}

Fonte: Arquivo Público Mineiro. Listas Nominativas de Habitantes de Nepomuceno: 1831-1832. 1832.

Giovanini (2006) e Coelho (2015) corroboram o elevado número de cativos nas propriedades agrícolas do sul de Minas na primeira metade do século $\mathrm{XIX}$, especialmente em comparação com as outras regiões do estado, ressaltando a importância do trabalho escravo para o desenvolvimento da cafeicultura na unidade federativa no começo dos oitocentos. Uma estratégia utilizada pelos proprietários sul-mineiros para a manutenção da força de trabalho escrava era a reprodução natural dos cativos (promovendo um crescimento natural positivo) ou a importação de outras áreas, sobretudo do porto do Rio de Janeiro. Todavia, Martins (1980) salienta que o crescimento vegetativo positivo

ParaOnde!?, Porto Alegre, v.13, n.1, p.189-213, 2020.http://seer.ufrgs.br/paraonde 
exerceu papel secundário na população cativa em Minas Gerais, pois a importação foi o principal fator que estimulou o crescimento do número de escravos no período oitocentista. Os escravos que chegavam a Minas Gerais eram oriundos principalmente do mercado carioca, pois a maioria dos escravos que migrava para o Brasil desembarcava no município do Rio de Janeiro, principal centro político do país naquele ínterim (GIOVANINI, 2006; COELHO, 2015).

Martins (2013) mostra que a partir do decênio de 1860, ocorreu a conjugação entre o trabalho escravo e o trabalho livre de imigrantes, sobretudo italianos, nas lavouras cafeeiras do sul de Minas Gerais. Castilho (2009) esclarece que a transição para a mão de obra assalariada foi um processo complexo na região, a qual apresentou grande número de escravos durante os oitocentos. Como o estado de Minas Gerais e, sobretudo as regiões Zona da Mata e Sul, apresentavam grande disponibilidade de terras desocupadas, a mão de obra livre era insuficiente. Assim, a opção dos fazendeiros era recorrer à força de trabalho escrava, uma vez que o fácil acesso às terras era um empecilho à proletarização do trabalhador livre e à sua submissão ao patronato (MARTINS, 1980; PASCOAL, 2005; 2007; COELHO, 2015).

Martins (1980) afirma que o camponês não era proletário em terras mineiras durante o século XIX, pois era autossuficiente e comandava as decisões fundamentais de suas unidades econômicas. Além disso, as oscilações do mercado praticamente não afetavam o funcionamento de suas propriedades, tampouco sua condição de vida. Numa sociedade escravocrata, os homens livres possuíam aversão ao trabalho, pois desejavam uma posição hierárquica superior, de caráter patronal. O trabalho, especialmente em atividades que exigiam força física, era função atribuída aos escravos. Os trabalhadores livres almejavam a manutenção de um status social superior. Ademais, as remunerações pagas ao trabalho agrícola eram diminutas, desestimulando os trabalhadores assalariados a ocuparem funções vinculadas à agropecuária, sobretudo aquelas que demandavam longos períodos de trabalho (MARTINS, 1980; PASCOAL, 2005; 2007).

Coelho (2015) e Vilas Boas (2016) afirmam que a Lei Geral de Terras, instituída em 1850, transformou a terra em mercadoria, cujo acesso era possibilitado somente através de compra, troca ou doação estatal. A implantação desta lei beneficiou as elites nacionais, estreitou a influência da disparidade de renda sobre a concentração fundiária no Brasil e dificultou o acesso de trabalhadores livres nacionais e estrangeiros e de escravos libertos à propriedade fundiária. Sua promulgação teve como alguns de seus principais objetivos a organização e a consolidação da propriedade privada da terra em território brasileiro. Salienta-se que a legislação mencionada estava atrelada à Lei Eusébio de Queiroz, a qual decretou a proibição do tráfico de escravos também no ano de 1850. Neste contexto, pressionados pelos ingleses desde 1807 , os portugueses assinaram diversos documentos e leis que gradualmente indicavam para a possibilidade de término do comércio de escravos e do regime escravocrata (JAHNEL, 1987).

Assim, houve redução da quantidade de terras livres em Minas Gerais,

ParaOnde!?, Porto Alegre, v.13, n.1, p.189-213, 2020.http://seer.ufrgs.br/paraonde 
colaborando para o aumento do número de trabalhadores sem-terra e de mão de obra disponível ao trabalho assalariado livre e, por conseguinte, suscetível à proletarização (COELHO, 2015). Todavia, Martins (1980) explica que mesmo após a promulgação da Lei de Terras, o acesso à terra, a despeito de sua conversão em mercadoria, continuou relativamente fácil, pois o preço cobrado pela terra em muitas regiões mineiras era irrisório, surpreendendo principalmente os europeus. A abundância de terras favoreceu as migrações internas em território mineiro, contribuindo para a manutenção do regime escravocrata, pois minorava a quantidade de mão de obra livre assalariada. Embora desde o início do século XIX existissem movimentos em diversos países em prol da abolição da escravatura, o sistema escravista só foi legalmente extinto no Brasil no ano de 1888, com a promulgação da Lei Áurea.

Contudo, o trabalho escravo persiste de modo ilegal no Brasil até os dias atuais, em locais como carvoarias e seringais, onde o aviamento é praticado cotidianamente, submetendo milhares de brasileiros a regimes escravos de trabalho (RIBEIRO, 2010; BRASIL, 2018). Conforme explica Oliveira (2016), a subordinação da agricultura brasileira ao modo de produção capitalista favorece a perpetuação da violência no campo. A pobreza da população rural, a fragilidade das leis direcionadas aos trabalhadores rurais, a ineficiência da fiscalização, a alta concentração fundiária, a exiguidade de políticas públicas voltadas aos camponeses e a associação entre agricultura patronal e política no país são alguns aspectos da estrutura agrária nacional que favorecem a existência de práticas de trabalho análogo à escravidão no campo brasileiro.

No desfecho dos anos 1850, o preço do café brasileiro no mercado internacional apresentou considerável aumento em virtude do crescimento da economia europeia. Entre 1857 e 1863, o preço médio da rubiácea brasileira exportada apresentou aumento de 50\%. Como a mão de obra escrava ainda era preponderante nas lavouras cafeeiras, a proibição do tráfico de escravos instituída pela lei Eusébio de Queiroz minorou a oferta de força de trabalho. A partir da década de 1860, em decorrência da valorização do grão, houve ampliação das lavouras cafeeiras em território brasileiro, motivando grande mobilidade interna de mão de obra. Todavia, neste mesmo período, a produção dos concorrentes brasileiros, como os países asiáticos e centro-americanos, apresentou expressivo crescimento, provocando posterior queda nos preços. A produção cafeeira da América Central aumentou de 400 mil sacas anuais para quase 800 mil sacas por ano, enquanto a produção asiática passou de 1,8 milhões para 2,2 milhões de sacas anuais (DELFIM NETTO, 2009).

A partir de 1850, com a promulgação da Lei Eusébio de Queiroz, o escravo se tornou uma mercadoria rara, cuja principal consequência foi o aumento de seu valor venal. Doravante, muitos escravos oriundos da decadente cultura canavieira no Nordeste foram comprados pelos cafeicultores do Sudeste, principalmente os paulistas. Mesmo antes da metade do século XIX, já existiam críticas acerca da baixa produtividade do trabalho escravo. No decênio de 1870, muitos fazendeiros paulistas optaram pelo emprego de mão de obra assalariada nos cafezais, pois a produtividade de seu trabalho era superior à da força de trabalho escrava. Com a abolição da escravatura, o governo brasileiro estimulou a vinda de imigrantes para trabalharem na cafeicultura. Neste período, muitos

ParaOnde!?, Porto Alegre, v.13, n.1, p.189-213, 2020.http://seer.ufrgs.br/paraonde 
colonos estrangeiros partiram em direção ao Brasil, sobretudo à unidade federativa de São Paulo (MARTINS, 1990; ARAÚJO FILHO, 1992). No entanto, embora a mão de obra assalariada apresentasse algumas vantagens aos proprietários fundiários, também onerava os gastos, uma vez que havia a necessidade de construção de moradias, geralmente precárias, para os novos colonos (DELFIM NETTO, 2009).

Na segunda metade do século XIX, as lavouras cafeeiras se expandiram para diversos municípios sul-mineiros, como Lavras, Bom Sucesso, Perdões e Nepomuceno (CASTILHO, 2009; SILVA, 2012). Em Perdões e Lavras, a cafeicultura não obteve a pujança econômica conquistada em Nepomuceno, onde desde o princípio dos novecentos, constitui a base da economia municipal (VILAS BOAS, 2016). Nesta conjuntura, o surgimento das primeiras lavouras cafeeiras na região culminou em drástico desmatamento da vegetação nativa. Em contrapartida, a pecuária, atividade muito desenvolvida em terras sulmineiras durante os oitocentos, forneceu grande quantidade de esterco de curral para a adubação orgânica, beneficiando os cafeicultores (COELHO, 2012).

\section{A importância do ferroviarismo para a cafeicultura sul-mineira no final do século $X I X$ e início do século $X X$}

Em 1852, o governo brasileiro decretou uma lei garantindo diversas vantagens àqueles que construíssem vias férreas no país, independente de sua nacionalidade. No rol dos benefícios assegurados pela nova legislação, figuravam a garantia de juros sobre os investimentos efetuados e as isenções fiscais. O Brasil seguiu o modelo adotado em países como Rússia, França e Inglaterra. Todavia, a fragilidade de seu mercado interno e o elevado custo de construção das ferrovias constituíram um empecilho ao desenvolvimento do transporte ferroviário no Brasil (SILVA, 2012).

Na década de 1870, período em que se iniciou a difusão de ferrovias pelo território brasileiro, o café foi responsável por mais da metade do valor financeiro das exportações brasileiras. Até os anos 1860, as tropas constituíam o principal meio de transporte da rubiácea das áreas cafeicultoras em direção aos portos. À época, a maioria do café era conduzida rumo a inúmeros portos secundários, de onde era levado, através da navegação de cabotagem, até os principais portos exportadores do país. Neste contexto, as rotas anteriormente construídas para escoamento da produção das zonas mineradoras foram importantes vias utilizadas para o transporte cafeeiro. Com o crescimento da cafeicultura e a produção em áreas mais longínquas em relação aos portos, as tropas foram gradativamente substituídas pelas ferrovias, visando desonerar e acelerar o escoamento da rubiácea (ARAÚJO FILHO, 1992).

A conjuntura internacional colaborou para a disseminação da cafeicultura em território brasileiro nos anos 1870 , pois o aumento do valor venal do café no mercado mundial entre 1870 e 1873 estimulou o surgimento de novos cafezais no Brasil e em outras nações latino-americanas. O sucesso das economias europeias e estadunidense neste período, aliado à geada de 1870 que devastou diversas lavouras cafeeiras no estado de São Paulo, contribuiu para a valorização internacional do grão (DELFIM NETTO, 2009). A cafeicultura

ParaOnde!?, Porto Alegre, v.13, n.1, p.189-213, 2020.http://seer.ufrgs.br/paraonde 
sustentou o Segundo Reinado (1840-1889), período do império brasileiro comandado por Dom Pedro II, no qual as administrações municipais efetivaram ações que promoveram a melhoria da infraestrutura nos setores de transporte, educação, saúde, saneamento e comunicação (ARAÚJO FILHO, 1992).

A Lei Áurea, promulgada em 1888, extinguiu a escravatura, porém, não ressarciu os agricultores que possuíam escravos. Esse argumento foi utilizado pela aristocracia rural em suas críticas à legislação citada, pois estes indivíduos se sentiram "prejudicados" com a sanção da lei. Doravante a abolição da escravidão, houve pressão social pelo fim da monarquia, até que em novembro de 1889, uma insurreição comandada pelos militares e liderada pelo Marechal Manuel Deodoro da Fonseca, anunciou a proclamação da República, respaldada pelo apoio dos cafeicultores, grupo com expressivo poder político durante a Primeira República (MARTINS, 1990; ARAÚJO FILHO, 1992).

A abundância de terras livres favoreceu o uso indiscriminado dos solos e, consequentemente, seu esgotamento, sobretudo no estado de São Paulo. Quando a fertilidade do solo diminuía, o cafeicultor adquiria outras terras de elevada fertilidade natural. A exaustão dos solos do Vale do Paraíba paulista no decênio de 1880 devido ao uso intenso para a produção cafeeira ilustra com clareza esse fenômeno (HOLLOWAY, 1978). De modo geral, a cafeicultura intensiva reduz significativamente a fertilidade dos solos, levando-os ao esgotamento, em função de diversos processos, como a erosão, a oxidação da matéria orgânica e a acidificação dos solos. A exportação de nutrientes, a qual consiste na retirada dos nutrientes do solo pelas plantas, também atua na diminuição da fertilidade (PRIMAVESI, 1984; 2014; BROGGIO et al., 1999).

Frederico (2017) denomina o intervalo compreendido entre a introdução das primeiras mudas de café em território brasileiro, no início dos setecentos, e os decênios de 1870-1880, como "Primórdios da Cafeicultura e o Meio Natural", período em que a produção cafeeira nacional esteve concentrada no Vale do Paraíba paulista e fluminense, no sul do Espírito Santo e na Zona da Mata Mineira. Neste ínterim, existiam poucos aparatos técnicos disponíveis aos cafeicultores. Predominavam a cafeicultura itinerante, a mão de obra escrava e o uso intensivo e predatório dos recursos naturais, sobretudo o solo. A adubação ainda não era realizada com frequência, especialmente em decorrência da elevada disponibilidade de terras ociosas. Por conseguinte, o desmatamento e os processos erosivos eram intensificados. Baseado na obra de Milton Santos (2006), Frederico (2017) afirma que este período é caracterizado pelo meio natural, em virtude da escassez de instrumentos técnicos e da influência direta que as características físicas (solo, topografia, clima, entre outras) dos municípios exerciam sobre a agricultura.

A cafeicultura e a construção de ferrovias conectando o sul de Minas a São Paulo e ao Rio de Janeiro favoreceram o desenvolvimento econômico da região na segunda metade do século XIX, especialmente no último quartel, época em que houve a disseminação do cultivo comercial do café nos municípios sul-mineiros. A expansão das estradas férreas pela região intensificou as relações comerciais com paulistas e fluminenses. A partir das décadas de 1870 e 1880, o sul de Minas aumentou significativamente sua participação na

ParaOnde!?, Porto Alegre, v.13, n.1, p.189-213, 2020.http://seer.ufrgs.br/paraonde 
exportação total de café do estado, a qual era praticamente inexpressiva em décadas anteriores. Como consequência, houve grande importação de escravos neste período, em virtude da renda gerada pela agricultura de abastecimento e pelo crescimento da cafeicultura. A inauguração da estação ferroviária de Três Corações no ano de 1884 e a construção em 1886 de um ramal da Estrada de Ferro Mogiana conectando Poços de Caldas a Cascavel favoreceram a exportação da produção cafeeira sul-mineira (GIOVANINI, 2006; CASTILHO, 2012; MARTINS, 2013).

Desta maneira, pode-se afirmar que a cafeicultura foi introduzida em larga escala na economia sul-mineira a partir do derradeiro quartel do século XIX, devido à expansão dos cafezais paulistas (FILETTO, 2000; SOUZA, 2006; CASTILHO, 2009; 2012). Doravante o decênio de 1870, a participação da região na produção estadual da rubiácea foi aumentando gradativamente. Portanto, o sul de Minas não era uma importante zona cafeeira no período imperial. Assim sendo, é equivocado afirmar que o sul de Minas atraiu um grande contingente de escravos para trabalhar nos cafezais no século XIX, visto que a mão de obra cativa era principalmente direcionada às atividades de autossuficiência das propriedades agrícolas (MARTINS, 1980).

A expansão do ramal da Mogiana Estradas de Ferro foi um importante elemento para a integração do sul de Minas Gerais ao eixo de expansão da cafeicultura no término do período oitocentista. Neste ínterim, o café sul-mineiro era transportado através de carros de boi até as estações férreas da Companhia Mogiana, de onde seguia para o porto de Santos (IBGE, 2016). Na transição entre os séculos XIX e XX, a maioria do café mineiro passou a ser exportado pelo porto do Rio de Janeiro, contrariando uma tendência nacional, visto que nos primeiros anos do século $X X$, o porto de Santos escoava praticamente todo o café brasileiro e quase metade da produção mundial da rubiácea (HOLLOWAY, 1978).

A maioria dos ramais e ferrovias construídos no final dos oitocentos possuía como objetivo conectar a produção agrícola sul-mineira (principalmente a cafeeira) aos mercados paulista e fluminense. Desta maneira, o investimento no setor ferroviário e a abundância de terras férteis e baratas foram cruciais à evolução da cafeicultura nos municípios sul-mineiros (CASTILHO, 2009; 2012). $\mathrm{Na}$ década de 1890, o transporte hidroviário foi desenvolvido nos rios Sapucaí e Grande, através de uma articulação com o sistema ferroviário (MARTINS, 2014b). Assim como o transporte marítimo, o transporte fluvial, em menor escala, foi importante ao escoamento da produção cafeeira durante um longo período. Neste contexto, Ribeirão Vermelho apresentava um transporte fluvial desenvolvido, com barcos a vapor que navegavam pelo Rio Grande, descarregando e embarcando diversas mercadorias, sobretudo café. A rubiácea transportada, após desembarcar em Ribeirão Vermelho, seguia até Lavras para ser escoada através da ferrovia até os portos de Angra dos Reis e do Rio de Janeiro (COELHO, 2012).

Nos últimos decênios dos oitocentos, percentual expressivo da produção agropecuária nepomucenense, inclusive a cafeeira, era transportado por meio do rio Grande e do rio do Cervo até as vias férreas mais próximas, de onde partia

ParaOnde!?, Porto Alegre, v.13, n.1, p.189-213, 2020.http://seer.ufrgs.br/paraonde 
principalmente em direção aos estados do Rio de Janeiro e São Paulo. Neste contexto, o Porto dos Mendes foi muito importante ao transporte fluvial de carga e passageiros de Nepomuceno e dos municípios adjacentes durante o século XIX e o início do XX. À época, o porto era um centro intermediário no trajeto entre Lavras (via porto de Ribeirão Vermelho) e a cidade de Piumhi. A partir dos novecentos, com o posterior desenvolvimento do transporte ferroviário na região e os frequentes surtos de malária, o transporte fluvial entrou em decadência no município e em seu entorno (VACA, 2013).

Assim sendo, a cafeicultura é tradicional no sul de Minas Gerais desde 0 final do século XIX, com a predominância de pequenos agricultores entre os produtores de café. A fertilidade, a abundância de terras livres e seu baixo preço favoreceram a disseminação das lavouras cafeeiras no sul do estado (CASTILHO, 2009). Corroborando a assertiva, no decênio de 1880, Nepomuceno possuía mais de cem mil cafezais plantados, marca bastante expressiva para a época (SILVA, 2012). Ademais, a diversidade de cafés cultivados, o dinamismo e o expressivo volume da produção cafeeira se destacam nos municípios sul-mineiros a partir do término do período oitocentista (BROGGIO et al., 1999). Holloway (1978) salienta a importância do desenvolvimento do sistema de parceria nas zonas cafeicultoras do Vale do Paraíba paulista e de Minas Gerais na passagem do século XIX para o XX, corroborando o adentramento de práticas e relações capitalistas de trabalho e de produção na agricultura nacional e regional. Acerca do tema, Martins (1990) afirma que o sistema de parceria é empregado na cafeicultura brasileira desde meados do século XIX.

De acordo com Giovanini (2006), em finais do século XIX e no início do século XX, houve significativa migração de lavouras cafeeiras da Zona da Mata Mineira para o sul do estado, contribuindo para o crescimento econômico de seus municípios. Aliada ao processo mencionado, a expressiva evolução da malha ferroviária sul-mineira nos decênios de 1890 e 1900, com a construção de importantes vias, como as Estradas de Ferro de Muzambinho e de Sapucaí, explica, em partes, o sucesso da cafeicultura na região neste ínterim. Nos anos 1890, a produção cafeeira no sul de Minas Gerais atingiu números consideráveis, ameaçando a hegemonia da Zona da Mata mineira no setor (CASTILHO, 2009). Segundo Castilho (2012), as ferrovias citadas vivenciaram dificuldades financeiras no término do período oitocentista. Agravando o cenário de crise, as greves promovidas pelos trabalhadores ferroviários constituíram um empecilho temporário ao êxito das estradas de ferro na região. Ao final do movimento grevista, como represália pela articulação das paralisações e dos protestos, seus líderes foram demitidos.

O papel dos políticos sul-mineiros, os quais tinham grande influência no cenário político estadual e federal, especialmente entre 1890 e 1910, foi fundamental ao desenvolvimento do setor ferroviário no estado, pois favoreceu a obtenção de investimentos e recursos financeiros e a aprovação de diversos projetos e subsídios atrelados às ferrovias. Muitas estradas férreas foram construídas com base nas rotas percorridas pelos tropeiros, aproveitando redes de comunicações e de transportes já consolidadas. Tal fato também demonstra a ausência de planejamento para a construção dessas vias (SILVA, 2012).

ParaOnde!?, Porto Alegre, v.13, n.1, p.189-213, 2020.http://seer.ufrgs.br/paraonde 
Com a disseminação das ferrovias no sul de Minas, cujo início se deu no final do século XIX, a cultura canavieira foi paulatinamente perdendo espaço para a cafeicultura, a qual era destinada à exportação, distinguindo-se da canade-açúcar e de seus derivados, os quais eram geralmente destinados ao mercado interno ou ao autoconsumo. O grande aumento da importação de cana pelos municípios sul-mineiros nos últimos anos dos oitocentos e no início dos novecentos corrobora o fato mencionado (SILVA, 2012). Entre 1880 e 1925, a produção canavieira nepomucenense foi expressiva, rivalizando com o cultivo de cereais e de café (PREFEITURA MUNICIPAL DE NEPOMUCENO, 1918; 1922; NAÇÃO BRASILEIRA, 1925). Doravante a década de 1930, a área destinada às lavouras canavieiras, assim como a produção de açúcar e aguardente, apresentou significativa redução em Nepomuceno, seguindo a tendência observada em toda a região.

Martins (2014b) destaca o notório crescimento demográfico no sul de Minas Gerais no findar dos oitocentos e no início dos novecentos, o qual, aliado à cafeicultura, reverberou na intensificação do desflorestamento da vegetação nativa, ocasionando danos ambientais irreparáveis e grande perda de diversidade da fauna e da flora regionais. No município de Nepomuceno não foi diferente, pois as vegetações de savana e de floresta estacional semidecidual, características do Cerrado e da Mata Atlântica, respectivamente, também foram bastante desmatadas (VILAS BOAS, 2016). Neste mesmo período, houve a difusão da cafeicultura, a modernização da pecuária sul-mineira e dos meios de transporte, com a disseminação das ferrovias. Na virada para o século XX, a cafeicultura promoveu transformações expressivas nas paisagens rurais e urbanas, as quais experimentaram algumas mudanças, como a chegada da eletricidade e das primeiras linhas telefônicas, a construção de estradas e 0 calçamento de ruas, além da instituição de sistemas de abastecimento de água (ARAÚJO FILHO, 1992; CASTILHO, 2009; MARTINS, 2014b).

Ao final do século XIX, o porto de Santos se tornou o maior exportador de café do mundo, principalmente em decorrência da construção da Estrada de Ferro Santos-Jundiaí, ferrovia inicialmente conhecida como São Paulo Railway Company, a qual conectou o litoral (sobretudo o município de Santos) ao interior paulista, com destaque para a região de planalto, área onde era cultivado o café no estado de São Paulo. A terra roxa, de elevada fertilidade e rica em potássio e ferro, fornecia os nutrientes necessários à cultura cafeeira (HOLLOWAY, 1978). Corroborando a importância do Brasil no cenário agrícola mundial, Martins (1990) aponta que no decênio de 1880, o país foi responsável por mais da metade de todo o café exportado no planeta (MARTINS, 1990). Acerca do impacto ocasionado pela implantação do transporte ferroviário em países subdesenvolvidos, Kautsky (1980, p. 143-144) disserta:

\footnotetext{
Mas as estradas de ferro construídas em países atrasados do ponto de vista econômico exercem ação diversa. Elas também determinam uma certa superprodução de gêneros alimentícios. Na medida em que ampliam o abastecimento dessas utilidades, alargam também 0 mercado urbano e contribuem para o crescimento da população industrial, que não poderia desenvolver-se tão depressa sem a importação de gêneros alimentícios de além-mar.
}

ParaOnde!?, Porto Alegre, v.13, n.1, p.189-213, 2020.http://seer.ufrgs.br/paraonde 
O excerto em destaque se articula com o panorama brasileiro do início do século $X X$, pois o desenvolvimento do sistema ferroviário favoreceu 0 escoamento da produção cafeeira. Construída com um expressivo aporte de capital estrangeiro, especialmente inglês, a estrada de ferro São Paulo Railway Company conectava Santos a Jundiaí, passando pela capital paulista. Projetada por engenheiros ferroviários ingleses de vasta experiência e com diversas obras concluídas na Europa e na América do Sul, a ferrovia ratificou a importante função do porto de Santos para a economia brasileira (ARAÚJO FILHO, 1992; CYRINO, 2004; SOUZA, 2006).

Kautsky (1980) observou que uma das possíveis aplicações do capital financeiro europeu no final do século XIX e no início dos novecentos era o setor ferroviário, especialmente em países subdesenvolvidos, cujo mercado consumidor, assim como as fontes de matérias-primas, interessava bastante às nações europeias. Neste ínterim, o caso brasileiro ilustra de maneira satisfatória a fala do autor, pois diversas ferrovias, como a São Paulo Railway Company, foram instaladas em território nacional como um investimento das finanças europeias, sobretudo para o escoamento da produção cafeeira (CYRINO, 2004). Contudo, nos derradeiros anos do século XIX, a economia paulista vivenciou um período de estagnação, associado à crise do setor cafeeiro (TAUNAY, 1939).

\section{A produção agropecuária nepomucenense nos decênios de 1910 e 1920 e o crescimento da cafeicultura municipal}

De acordo com os dados da tabela 02, no início do século XX, a produção cafeeira já era a maior fonte agrícola de renda monetária em Nepomuceno, embora fosse inferior, em volume total, à produção de milho. Contudo, a cultura canavieira apresentava cifras expressivas, com destaque para a produção de açúcar e principalmente de cachaça, cuja fabricação era responsável pelo maior valor monetário de produção no município. Neste período, a produção de cana e de seus derivados era proeminente nas propriedades sul-mineiras $\mathrm{O}$ cultivo de cereais e a indústria pastoril também eram importantes atividades econômicas municipais, com a pecuária bovina e a criação de cavalos e muares ocupando, empatadas, o posto de segunda maior fonte de renda monetária de Nepomuceno em 1918 (PREFEITURA MUNICIPAL DE NEPOMUCENO, 1918; CASTILHO, 2009; VILAS BOAS, 2016)

ParaOnde!?, Porto Alegre, v.13, n.1, p.189-213, 2020.http://seer.ufrgs.br/paraonde 
Tabela 02 - Município de Nepomuceno: Valor Estimado da Produção em 1918 (em Réis)

\begin{tabular}{cc}
\hline Produto & Valor Estimado da Produção \\
\hline Aguardente de Cana & $3.117: 700 \$ 000$ \\
Bovinos & $1.500: 000 \$ 000$ \\
Cavalos e Muares & $1.500: 000 \$ 000$ \\
Café & $1.080: 000 \$ 000$ \\
Milho & $750: 000 \$ 000$ \\
Feijão & $300: 000 \$ 000$ \\
Suínos & $300: 000 \$ 000$ \\
Arroz & $240: 000 \$ 000$ \\
\hline
\end{tabular}

Fonte: PREFEITURA MUNICIPAL DE NEPOMUCENO. Estatística do Município de Nepomuceno. 1918

Apesar de ser o principal produto da agricultura nepomucenense no início dos novecentos, o café ainda não ocupava a maioria das terras municipais em 1918, pois vastas extensões de terras eram destinadas à pecuária e ao cultivo de cereais. À época, a cafeicultura ocupava apenas 2 mil alqueires no município, enquanto as áreas destinadas à plantação de cereais totalizavam 8 mil alqueires e as pastagens voltadas à pecuária somavam 6 mil alqueires. Neste ano, a produção de café foi inferior à de milho, conforme ilustra a tabela 03 . O direcionamento da safra cafeeira à exportação e o plantio de milho para alimentação do gado suíno e bovino auxiliam na compreensão desta situação, pois enquanto a maioria do café colhido em Nepomuceno era voltada à venda, parcela considerável do milho produzido era utilizada para autoconsumo (PREFEITURA MUNICIPAL DE NEPOMUCENO, 1918).

\begin{tabular}{cc} 
Tabela 03 - Nepomuceno: Produção Agrícola \\
em Arrobas - $\mathbf{1 9 1 8}$ \\
\hline Milho & 250.000 \\
Café & 180.000 \\
Feijão & 60.000 \\
Açúcar & 50.000 \\
Arroz & 40.000 \\
Mandioca & 3.000 \\
Algodão & 1.000 \\
Batata & 200 \\
\hline
\end{tabular}

Fonte: PREFEITURA MUNICIPAL DE NEPOMUCENO.

Estatística do Município de Nepomuceno. 1918.

Em 1918, o município também se destacava na pecuária, com um total de 15 mil reses bovinas, 12 mil reses suínas, 1.500 cabeças de cabras e ovelhas e 70 mil cabeças de aves. Sua produção anual de manteiga foi de vinte toneladas

ParaOnde!?, Porto Alegre, v.13, n.1, p.189-213, 2020.http://seer.ufrgs.br/paraonde 
e a de queijo correspondeu a doze toneladas, números expressivos para a época. Nepomuceno também possuía fábricas de queijo e de manteiga, as quais comercializavam laticínios para diversas cidades da região (PREFEITURA MUNICIPAL DE NEPOMUCENO, 1918). Ressalta-se que a cafeicultura só veio a ocupar o posto de principal atividade econômica do município, em termos de área ocupada, valor e volume total da produção, no decênio de 1930 (VILAS BOAS, 2016). No mesmo período, a chegada de italianos, libaneses e suíços ao município favoreceu o crescimento da cafeicultura local (PREFEITURA MUNICIPAL DE NEPOMUCENO, 1918; 1922; NAÇÃO BRASILEIRA, 1925). À época, milhares de italianos abandonaram o estado de São Paulo em virtude da crise de superprodução cafeeira e migraram em direção a outras regiões, como o sul de Minas (HOLLOWAY, 1978). Muitos dos italianos que se aventuravam em terras brasileiras tinham parentes e pessoas conhecidas no país, as quais incentivavam a vinda para o Brasil, auxiliando-os na procura por emprego (COELHO, 2012).

As ferrovias e as estações férreas construídas na transição entre os séculos XIX e XX contribuíram para a chegada dos italianos aos municípios sulmineiros (MARTINS, 2014a). Alguns estrangeiros fixaram residência no município de Nepomuceno, trazendo consigo os conhecimentos e as técnicas de trabalho e de produção empregados na cafeicultura paulista. No tocante ao assunto, Filetto (2000) e Giovanini (2006) mostram que já no final do século XIX, assim como no início do XX, houve a expansão de terras cafeicultoras paulistas para a porção sul do estado de Minas Gerais, região de maior declividade, cuja fertilidade natural dos solos era menor em relação ao Vale do Paraíba paulista, afamado pela aptidão da terra roxa à cafeicultura.

Salienta-se que, no final do século XIX, a Itália vivenciava um momento conturbado, em virtude do conflito atrelado ao movimento de unificação do país. Havia também uma severa crise econômica, cujas consequências eram as elevadas taxas de desemprego, o arrocho salarial, os surtos de fome e de miséria, a expropriação dos camponeses, entre outras (MARTINS, 1990). O cenário caótico italiano, associado às políticas estatais de atração de imigrantes, cujos principais intuitos eram o crescimento da mão de obra assalariada e a tentativa eugenista de branqueamento da população brasileira, fomentaram a grande migração de italianos em direção ao Brasil. Muitos imigrantes partiram do porto de Gênova e desembarcaram nos portos de Rio de Janeiro e de Santos. Em território nacional, a maioria dos italianos foi inicialmente direcionada à cafeicultura no estado de São Paulo (HOLLOWAY, 1978; MATOS, 2011; SANTOS, 2014).

Em função dos reflexos da crise de superprodução cafeeira dos primeiros anos do século XX em terras paulistas, muitos estrangeiros migraram para o sul de Minas Gerais e o município de Nepomuceno, onde desempenharam importante papel no desenvolvimento da cafeicultura local. Neste cenário, Castilho $(2009 ; 2012)$ ressalta a relevância do transporte ferroviário para a chegada de mão de obra imigrante (sobretudo italiana) aos municípios sulmineiros. No ano de 1897, aproximadamente 770 italianos migraram para o sul de Minas em decorrência do trabalho nas ferrovias. Araújo Filho (1992) mostra que apenas em 1895, aproximadamente 140 mil imigrantes estrangeiros

ParaOnde!?, Porto Alegre, v.13, n.1, p.189-213, 2020.http://seer.ufrgs.br/paraonde 
entraram no estado de São Paulo. Já Castilho (2009), disserta que o ínterim compreendido entre 1888 e 1898 foi o período de maior ingresso de imigrantes no estado de Minas Gerais, com destaque para o ano de 1896, no qual mais de 25 mil estrangeiros adentraram o território mineiro.

De acordo com a Estatística do Município de Nepomuceno, documento elaborado pela Prefeitura Municipal (1918), Nepomuceno possuía 13.258 habitantes, com 12.675 brasileiros e 583 estrangeiros, cuja maioria era composta por italianos. Todavia, estima-se que o número de estrangeiros fosse maior, pois era comum a naturalização dos forasteiros após algum tempo de estadia no país. Ademais, muitos estrangeiros já haviam migrado para os municípios adjacentes, enquanto outros tiveram filhos no próprio município. Conforme enuncia o periódico Nação Brasileira (NAÇÃO BRASILEIRA, 1925), alguns imigrantes italianos que haviam deixado Nepomuceno fizeram a migração de retorno após alguns anos, regressando ao município. Segundo o Livro do Centenário (PREFEITURA MUNICIPAL DE NEPOMUCENO, 1922), a elevada fertilidade pedológica de Nepomuceno colaborou para a imigração de italianos, cuja contribuição para a cafeicultura municipal foi inequívoca.

Araújo Filho (1992) afirma que houve redução da imigração de trabalhadores estrangeiros em direção ao território brasileiro após a Primeira Guerra Mundial. O decréscimo da vinda de europeus para o Brasil foi intensificado após a crise de 1929. Doravante a recessão, em virtude da diminuição da oferta de força de trabalho estrangeira, a mão de obra do norte de Minas Gerais e do Nordeste ganhou espaço na cafeicultura nacional e sulmineira.

Percentual expressivo da produção cafeeira nepomucenense era escoado através do ramal ferroviário entre as estações de Três Corações e de Lavras (onde atualmente se localiza o município de Ribeirão Vermelho). Pertencente à Estrada de Ferro Oeste de Minas, o ramal distava cerca de 18 quilômetros da sede de Nepomuceno. Neste contexto, o transporte constituía o principal empecilho ao êxito da cafeicultura local, pois era muito vagaroso, onerando a produção. Além disso, o elevado custo dos fretes e carretos e a possível deterioração da produção durante o transporte prejudicavam as vendas da rubiácea cultivada no município. As etapas de produção, como beneficiamento, ensacamento e transporte, também elevavam consideravelmente o valor venal do café (PREFEITURA MUNICIPAL DE NEPOMUCENO, 1918).

No decênio de 1920, havia uma ótima estrada de rodagem, cuja construção foi promovida pelo político, industrial e agricultor Miguel Manzo, ligando Nepomuceno a Lavras. A rodovia foi importante para os cafeicultores nepomucenenses, pois facilitava o escoamento da produção e desonerava os gastos com transporte (NAÇÃO BRASILEIRA, 1925). A obra propiciou o aumento da extração de renda da terra diferencial II pelos agricultores municipais, pois conforme explicam Marx (1983) e Harvey (2013), a construção de estradas ou o melhoramento das vias promove o aumento da renda diferencial II, a qual deriva da aplicação de técnicas e investimentos nos solos.

A Agencia Ford e Officina Mechanica de Manzo e Bacarica, inaugurada em 1924, comercializou dezenas de automóveis num período de apenas um ano,

ParaOnde!?, Porto Alegre, v.13, n.1, p.189-213, 2020.http://seer.ufrgs.br/paraonde 
corroborando o crescimento industrial e financeiro e o desenvolvimento do transporte automobilístico em Nepomuceno nos anos 1920. Algumas propriedades fundiárias, como a Fazenda Bella Cruz, possuíam uma ampla frota de carros e caminhões (NAÇÃO BRASILEIRA, 1925). Neste período, a renda gerada pela cafeicultura possibilitou a aquisição de veículos, artigos valiosos para a época, por parte de alguns agricultores municipais.

\section{Considerações finais}

As condições geomorfológicas, climáticas e pedológicas da maioria dos municípios sul-mineiros e, particularmente de Nepomuceno, como a altimetria média, o clima tropical de altitude e os solos de elevada fertilidade, favoreceram o êxito da cafeicultura. No entanto, apesar da indiscutível contribuição dos fatores físicos para a disseminação das lavouras cafeeiras, as características socioeconômicas também colaboraram para sua difusão.

A mão de obra escrava foi muito utilizada nos cafezais sul-mineiros na primeira metade do século XIX. Os dados do Arquivo Público Mineiro confirmam que os municípios sul-mineiros apresentavam um percentual de escravos superior à média do estado e do país durante a primeira metade dos oitocentos (ARQUIVO PÚBLICO MINEIRO, 1832).

Ademais, sublinha-se que no início do século XX, a chegada de imigrantes italianos e a construção de ferrovias e hidrovias no Sul de Minas Gerais contribuíram para a disseminação das lavouras cafeeiras na região. Vias férreas foram essenciais para o escoamento da produção cafeeira regional, além de facilitarem a chegada de italianos, vindos principalmente do estado de São Paulo, que já dominavam as técnicas de trabalho e de produção nos cafezais. Já em Nepomuceno, o café só veio a se tornar a principal fonte de renda municipal no decênio de 1930. A mão de obra italiana, associada à construção de uma estrada de rodagem, cooperaram significativamente para 0 fortalecimento da cafeicultura local.

\section{Notas}

1 - Este artigo é parte da tese de doutorado apresentada e defendida junto ao Programa de Pós-Graduação em Geografia da Universidade Federal de Minas Gerais no ano de 2019.

\section{Referências}

ARAÚJO FILHO, J. R. O café, riqueza paulista. Boletim Paulista de Geografia, São Paulo, n. 68, p. 51-124, 1992.

ARQUIVO PÚBLICO MINEIRO. Listas Nominativas de Habitantes de Nepomuceno: 1831-1832. Belo Horizonte: Arquivo Público Mineiro, 1832.

BARBOSA, Y. A. Espaço, História e Cidade: Uma abordagem geográfica do processo urbano de Juiz de Fora na última década do século XIX. 2016. $249 \mathrm{f}$. Dissertação (Mestrado em Geografia) - Programa de Pós-Graduação em

ParaOnde!?, Porto Alegre, v.13, n.1, p.189-213, 2020.http://seer.ufrgs.br/paraonde 
Geografia, Universidade Federal de Juiz de Fora, Juiz de Fora, 2016.

BRASIL. Ministério do Trabalho. Cadastro de Empregadores que tenham submetido trabalhadores a condições análogas à de escravo. Brasília: Ministério do Trabalho, 2018. 15 p. Disponível em: <http://trabalho.gov.br/images/Documentos/cadastro_empregadores_2018.pdf> . Acesso em: 13 fev. 2019.

BROGGIO, C. ; DROULERS, M. ; GRANDJEAN, P. A Dinâmica Territorial da Cafeicultura Brasileira - Dois Sistemas de Produção em Minas Gerais. Revista TERRITÓRIO, Rio de Janeiro, v. 04, n. 06, p. 73-91, jan./jun. 1999.

CASTILHO, F. F. A. Entre a locomotiva e o fiel da balança: a transição da mão de obra no Sul de Minas (1870-1918). 2009. 177 f. Dissertação (Mestrado em História) - Programa de Pós-Graduação em História, Universidade Federal de Juiz de Fora, Juiz de Fora, 2009.

CASTILHO, F. F. A. As Estradas de Ferro do Sul de Minas. Heera - Revista de História Econômica \& Economia Regional Aplicada, Juiz de Fora, v. 07, n. 12, p. 43-63, jan./jun. 2012.

COELHO, A. J. E. Sul de Minas - Excelência em Café. Varginha: Edições Alba, 2012.

COELHO, P. H. L. Terra e Trabalho no Sul de Minas: produção de alimentos e mercado interno no século XIX. 2015. 193 f. Dissertação (Mestrado em História) - Programa de Pós-Graduação em História, Universidade Federal de Juiz de Fora, Juiz de Fora, 2015.

CYRINO, F. Café, Ferro e Argila: A história da implantação e consolidação da The San Paulo (Brazilian) Railway Company Ltda. através da análise de sua arquitetura. São Paulo: Landmark, 2004.

DELFIM NETTO, A. O problema do café no Brasil. 3. ed. São Paulo: Editora UNESP, 2009.

FILETTO, F. Trajetória Histórica do Café na Região Sul de Minas Gerais. 2000. 133 f. Dissertação (Mestrado em Administração Rural) - Programa de PósGraduação em Administração Rural, Universidade Federal de Lavras, Lavras, 2000.

FREDERICO, S. Lógica das commodities, finanças e cafeicultura. Boletim Campineiro de Geografia, Campinas, v. 03, n. 01, p. 97-116, 2013.

FREDERICO, S. Território e cafeicultura no Brasil: uma proposta de periodização. GeoUSP, São Paulo, v. 21, n. 01, p. 73-101, abr. 2017.

FUNDAÇÃO JOÃO PINHEIRO. Regiões de Planejamento. 3. ed. Belo Horizonte: FJP, 1992.

GIOVANINI, R. R. Regiões em Movimento - Um Olhar sobre a Geografia Histórica do Sul de Minas e da Zona da Mata Mineira (1808-1897). 2006. 204 f. Dissertação (Mestrado em Geografia) - Programa de Pós-Graduação em Geografia, Universidade Federal de Minas Gerais, Belo Horizonte, 2006.

HARVEY, D. Os Limites do Capital. Tradução: Magda Lopes. São Paulo:

ParaOnde!?, Porto Alegre, v.13, n.1, p.189-213, 2020.http://seer.ufrgs.br/paraonde 
Boitempo, 2013.

HOLLOWAY, T. H. Vida e Morte do Convênio de Taubaté: A Primeira Valorização do Café. Tradução: Marcio Doctors. Rio de Janeiro: Paz e Terra, 1978.

INSTITUTO BRASILEIRO DE GEOGRAFIA E ESTATÍSTICA. A Geografia do Café. Rio de Janeiro: IBGE/Coordenação de Geografia, 2016.

INSTITUTO BRASILEIRO DE GEOGRAFIA E ESTATÍSTICA. Produção Agrícola Municipal 2018. Rio de Janeiro: IBGE, 2019a.

INSTITUTO BRASILEIRO DE GEOGRAFIA E ESTATÍSTICA. Produto Interno Bruto dos Municípios: 2002-2017. Rio de Janeiro: IBGE, 2019b.

INSTITUTO BRASILEIRO DE GEOGRAFIA E ESTATÍSTICA. Estimativas de População 2019. Rio de Janeiro: IBGE, 2019c.

JAHNEL, T. C. As Leis de Terra no Brasil. Boletim Paulista de Geografia, São Paulo, n. 65, p. 105-116, 1987.

KAUTSKY, K. A Questão Agrária. 3. ed. São Paulo: Proposta Editorial, 1980.

MARTINS, R. B. A Economia Escravista de Minas Gerais no Século XIX. Belo Horizonte: CEDEPLAR/UFMG, 1980.

MARTINS, A. L. Império do Café: A grande lavoura no Brasil - 1850 a 1890. 7. ed. São Paulo: Atual, 1990.

MARTINS, M. L. Plantar, Pastorar e Fiar na Vila Formosa de Alfenas, MG: Décadas de 1850-1890. Estudos Econômicos, São Paulo, v. 43, n. 02, p. 397429, abr./jun. 2013.

MARTINS, M. L. A Marcha do Café no Sul de Minas, Décadas de 1880-1920: Alfenas, Guaxupé, Machado e Três Pontas. Revista Territórios \& Fronteiras, Cuiabá, v. 07, n. 01, p. 287- 320, jan./jun. 2014a.

MARTINS, M. L. Paisagens no sul de Minas: os ambientes rurais regionais e sua transformação pelo avanço da cafeicultura (décadas de 1870-1920). Revista de História Regional, Ponta Grossa, v. 19, n. 01, p. 127-155, 2014b.

MARX, K. O Capital (Crítica da Economia Política) - Livro 3 - O Processo Global de Produção Capitalista. Volume VI. Tradução: Moacyr Félix. 3. ed. Rio de Janeiro: Civilização Brasileira. 1983, p. 705-1079.

NEPOMUCENO, Nação Brasileira, Rio de Janeiro, ano 3, n. 19, p. 01-50, mar. 1925.

OLIVEIRA, M. M. Como fazer pesquisa qualitativa. 4. ed. Petrópolis: Vozes, 2012.

OLIVEIRA, A. U. A Mundialização da Agricultura Brasileira. São Paulo: Iãnde Editorial, 2016.

PASCOAL, I. Reprodução da Força de Trabalho no Sul de Minas - Século XIX - No Contexto de uma Formação Econômica Não-Exportadora. 2005. 255 f. Tese (Doutorado em Sociologia) - Programa de Pós-Graduação em Sociologia, Universidade de Campinas, Campinas, 2005.

ParaOnde!?, Porto Alegre, v.13, n.1, p.189-213, 2020.http://seer.ufrgs.br/paraonde 
PASCOAL, I. Economia e trabalho no sul de Minas no século XIX. Economia e Sociedade, Campinas, v. 16, n. 02, p. 259-287, ago. 2007.

PEREIRA, C. S. ; HESPANHOL, A. N. Região e regionalizações no estado de Minas Gerais e suas vinculações com as políticas públicas. Revista Formação, Presidente Prudente, v. 01, n. 22, p. 42-70, 2015.

PREFEITURA MUNICIPAL DE NEPOMUCENO. Estatística do Município de Nepomuceno. Aprovada no dia 15 de Setembro de 1918. Nepomuceno: Prefeitura Municipal de Nepomuceno, 1918.

PREFEITURA MUNICIPAL DE NEPOMUCENO. Livro do Centenário. Nepomuceno: Prefeitura Municipal de Nepomuceno, 1922.

PRIMAVESI, A. Manejo ecológico do solo: a agricultura em regiões tropicais. 6. ed. São Paulo: Livraria Editora Nobel, 1984.

PRIMAVESI, A. Pergunte ao Solo e às Raízes. São Paulo: Livraria Editora Nobel, 2014.

RECLUS, É. Estados Unidos DO BRASIL - Geographia, Ethnographia, Estatística. Tradução: B. F. Ramiz Galvão. Rio de Janeiro/Paris: H. Garnier, Livreiro Editor, 1900.

RIBEIRO, D. O Povo Brasileiro. 7ª Reimpressão. São Paulo: Companhia das Letras, 2010.

SANTOS, M. A Natureza do Espaço - Técnica e Tempo. Razão e Emoção. 4. ed. 2ª Reimpressão. São Paulo: EdUSP, 2006.

SANTOS, H. M. G. Notas sobre os projetos territoriais em torno da política de imigração e colonização em Minas Gerais (1892-1900). Caderno de Geografia, Belo Horizonte, v. 24, n. especial 01, p. 94-106, jun. 2014.

SILVA, M. P. De gado a café: as ferrovias no Sul de Minas Gerais (1874-1910). 2012. 205 f. Dissertação (Mestrado em História Econômica) - Programa de PósGraduação em História Econômica, Universidade de São Paulo, São Paulo, 2012.

SILVA, J. M. ; MENDES, E. P. P. Abordagem qualitativa e geografia: pesquisa documental, entrevista e observação. In: MARAFON, G. J. ; RAMIRES, J. C. L. ; RIBEIRO, M. A. ; PESSÔA, V. L. S. (Org.) Pesquisa qualitativa em geografia: reflexões teórico-conceituais e aplicadas. Rio de Janeiro: Editora da UERJ, 2013. p. 207-222.

SOUZA, M. C. M. Cafés Sustentáveis e Denominação de Origem: A Certificação de Qualidade na Diferenciação de Cafés Orgânicos, Sombreados e Solidários. 2006. 192 f. Tese (Doutorado em Ciência Ambiental) - Programa de Pós-Graduação em Ciência Ambiental, Universidade de São Paulo, São Paulo, 2006.

TAUNAY, A. E. História do Café no Brasil. Rio de Janeiro: Departamento Nacional do Café, 1939.

TOPIK, S. The integration of the world coffee market. In: CLARENCE-SMITH, W. G. ; TOPIK, S. (Org.). The global coffee economy in Africa, Asia and Latin

ParaOnde!?, Porto Alegre, v.13, n.1, p.189-213, 2020.http://seer.ufrgs.br/paraonde 
America - 1500-1989. Nova York: Cambridge University Press, 2003. p. 21-49.

VACA, S. T. História do Porto dos Mendes. Revista de Aniversário - Folha Independente em Revista, Nepomuceno, ano 07, n. 14, 2013.

VILAS BOAS, L. G. Segurança Alimentar e Relações Capitalistas no Campo e na Cidade: O Exemplo de Nepomuceno-MG. 2016. 233 f. Dissertação (Mestrado em Geografia) - Programa de Pós-Graduação em Geografia, Universidade Federal de Juiz de Fora, Juiz de Fora, 2016.

VILAS BOAS, L. G. A atuação das cooperativas na agricultura familiar do município de Nepomuceno-MG: integração ao modo de produção capitalista e perda de soberania alimentar. 2019. 328 f. Tese (Doutorado em Geografia) Programa de Pós-Graduação em Geografia, Universidade Federal de Minas Gerais, Belo Horizonte, 2019.

WATSON, K. ; ACHINELLI, M. L.. Context and contingency: the coffee crisis for conventional small-scale coffee farmers in Brazil. The Geographical Journal, Royal Geographical Society, v. 174, n. 03, p. 223-234, set. 2008. 